\title{
ANALISIS KELAYAKAN FINANSIAL PROYEK PLTN SMR DI INDONESIA DENGAN MEMPERTIMBANGKAN VARIABEL KETIDAKPASTIAN
}

\author{
Nuryanti, Suparman, Mochamad Nasrullah, \\ Elok Satiti Amitayani, Wiku Lulus Widodo \\ Pusat Kajian Sistem Energi Nuklir (PKSEN) BATAN \\ Jl. Kuningan Barat, Mampang Prapatan, Jakarta 12710 \\ Telp./Fax: (021)5204243,E-mail: nuryanti@batan.go.id
}

\begin{tabular}{|c|c|c|}
\hline Diterima & Diterima dalam bentuk revisi & Disetujui \\
\hline 06 Juli 2015 & 12 Nopember 2015 & 27 Nopember 2015 \\
\hline
\end{tabular}

\begin{abstract}
ABSTRAK
ANALISIS KELAYAKAN FINANSIAL PROYEK PLTN SMR DI INDONESIA DENGAN MEMPERTIMBANGKAN VARIABEL KETIDAKPASTIAN. SMR merupakan salah satu alternatif mengatasi ketergantungan wilayah Luar Jawa Bali terhadap PLTD. Masalah yang sangat krusial dalam proyek PLTN (termasuk SMR) adalah finansial, terkait dengan sifat padat modal pada proyek ini. Selain itu, pada proyek PLTN SMR juga dimungkinkan terjadinya beberapa variabel ketidakpastian. Penelitian ini bertujuan untuk melakukan analisis kelayakan finansial proyek PLTN SMR dengan mengakomodasi kemungkinan terjadinya variabel ketidakpastian tersebut. Metodologi yang digunakan adalah analisis probabilistik dengan teknik Monte Carlo. Teknik ini mensimulasikan keterkaitan antara variabel-variabel ketidakpastian dengan indikator kelayakan finansial proyek. Hasil penelitian menunjukkan bahwa pada pendekatan probabilistik proyek PLTN SMR dinilai layak pada "most probable value" harga jual listrik sebesar 15 cents/kWh, ditunjukkan dengan rata-rata NPV positif (US\$ 135.324.004) dan rata-rata kedua nilai IRR yang lebih dari MARR (IRR proyek= 10,65\%, IRR Equity $=14,29 \%$, sementara $M A R R=10 \%$ ). Probabilitas ditolaknya proyek PLTN SMR adalah sekitar $20 \%$. Tiga variabel utama yang paling berpengaruh dalam proyek adalah: harga jual listrik, biaya investasi dan tingkat inflasi.
\end{abstract}

Kata kunci: kelayakan finansial, PLTN SMR, variabel ketidakpastian, NPV, IRR.

\begin{abstract}
FINANCIAL FEASIBILITY ANALYSIS ON SMALL MEDIUM REACTOR NUCLEAR POWER PLANT (SMR NPP) PROJECT IN INDONESIA UNDER UNCERTAINTY. NPP $S M R$ is one alternative to overcome the Outside Java Bali region's dependence on diesel power plant. One crucial issue in the NPP project (including SMR) would be financing, associated with the capital-intensive nature of the project. In addition, the SMR NPP project also be vulnerable in occurrence of some uncertainties. Therefore, this study aimed to analyze the financial feasibility of SMR NPP project by accomadating the possibility of the uncertainties. The methodology used is probabilistic analysis which was performed by Monte Carlo technique. This technique simulates the relationship between the uncertainty variables with financial feasibility indicators. The results showed that in probabilistic approach, SMR NPP project is considered feasible on the "most probable value" of electricity selling price of 15 cents $/ \mathrm{kWh}$, indicated by positive average value of NPV (US\$ 135,324,004) and the average value of both of IRRs are bigger than MARR (IRR project = $10,65 \%$, IRR Equity $=14,29 \%$, while $M A R R=10 \%$ ). The probability of rejection of the SMR project was about $20 \%$. The three main variables that are most influential in the project were: selling price of electricity, invesment cost and inflation rate.
\end{abstract}

Keywords: financial feasibility, SMR NPP, uncertainties, NPV, IRR. 


\section{PENDAHULUAN}

Sistem kelistrikan Luar Jawa Bali (LJB) ditandai dengan sistem transmisinya yang belum seluruhnya terinterkoneksi. Sistem kelistrikan Kalimantan Barat misalnya, terdiri atas satu sistem interkoneksi (sistem Khatulistiwa), beberapa sistem terisolasi dan wilayah khusus yang listriknya bersumber dari Serawak - Malaysia ${ }^{[1]}$. Selain itu, sistem kelistrikan Luar Jawa Bali juga ditandai dengan masih banyaknya sistem di wilayah ini yang termasuk kategori daerah yang mengalami krisis penyediaan energi listrik. Oleh karena itu, penambahan pembangkit baru menjadi hal yang krusial untuk dilakukan. Sistem interkoneksi yang ada di wilayah ini umumnya merupakan sistem transmisi berukuran kecil. Sebagai contoh, pada tahun 2013 sistem pembangkitan Sumatra Bagian Utara (Sumbagut) memiliki total kapasitas terpasang sebesar 2.096,87 MW. Pada tahun yang sama, sistem interkoneksi Jawa Bali memiliki total kapasitas terpasang sebesar 26.768,45 $M W^{[2] . U n t u k ~ m e n j a m i n ~ k e a n d a l a n ~ s i s t e m, ~ k a p a s i t a s ~ m a k s i m a l ~ p e r ~ u n i t ~ y a n g ~ d i i j i n k a n ~ u n t u k ~}$ penambahan pembangkit baru adalah sebesar 10\% dari total kapasitas terpasang yang ada. Untuk sistem Sumbagut misalnya, dengan total kapasitas terpasang sebesar 2.096,87 MW, maka kapasitas maksimal unit pembangkit baru yang diijinkan adalah sekitar $200 \mathrm{MW}$. Dengan kata lain pembangkit skala kecil dan menengah merupakan jenis pembangkit yang cocok untuk dikembangkan pada sistem jaringan kelistrikan kecil (small grid) seperti di wilayah LJB. Untuk pilihan teknologi nuklir, maka dapat dikembangkan PLTN SMR (Small Medium Reactor - SMR). Selain karakteristik terkait kapasitas jaringan, sistem kelistrikan LJB juga ditandai dengan adanya dominasi pembangkit listrik tenaga diesel (PLTD). Dari 4.640 unit pembangkit yang ada, sekitar 4.368 unit $(94,14 \%)$ adalah PLTD dengan kapasitas terpasang mencapai $36,94 \%$ dari kapasitas total[2]. Fluktuasi harga bahan bakar minyak (BBM) serta rantai pasok BBM hingga ke lokasi PLTD menjadi persoalan yang menyebabkan tingginya biaya pembangkitan listrik di wilayah ini. Mengingat PLTN SMR cocok untuk dikembangkan di wilayah yang belum seluruhnya terinterkoneksi, maka PLTN SMR dapat menjadi salah satu alternatif mengatasi ketergantungan wilayah LJB terhadap pembangkit berbahan bakar minyak ${ }^{[3,4]}$.

Salah satu tantangan terbesar dalam pembangunan PLTN di Indonesia adalah masalah finansial, tak terkecuali pada PLTN SMR. Hal ini terkait dengan sifat proyek PLTN sebagai proyek padat modal dan padat teknologi serta dengan persyaratan keselamatan dan keamanan yang tinggi. Sifat ini tentu akan membuat calon investor sangat berhati-hati dalam pengambilan keputusan investasi. Selain itu, dalam proyek infrastruktur (termasuk PLTN) juga dimungkinkan untuk terjadinya beberapa variabel ketidakpastian yang berpotensi memunculkan resiko dalam proyek. Ketidakpastian biaya investasi, fluktuasi harga bahan bakar, dan faktor kapasitas pembangkit adalah beberapa contoh variabel ketidakpastian tersebut. Oleh karena itu diperlukan analisis kelayakan finansial yang mampu mengakomodasi kemungkinan terjadinya variabel-variabel ketidakpastian tersebut. Suatu pendekatan yang cukup komprehensif dalam mengakomodasi kemungkinan terjadinya sejumlah variabel ketidakpastian yang memunculkan resiko dalam proyek PLTN tersebut disebut analisis probabilistik ${ }^{[5]}$. Oleh karena itu, penelitian ini bertujuan untuk melakukan analisis kelayakan finansial proyek PLTN SMR di Indonesia dengan mempertimbangkan kemungkinan terjadinya beberapa variabel ketidakpastian dalam proyek. Kelayakan finansial proyek tercermin pada nilai beberapa indikator kelayakan finansial dan dalam penelitian ini digunakan indikator Nilai Kini Bersih (NPV - Net Present Value) dan Tingkat Pengembalian Internal (IRR - Internal Rate of Return) ${ }^{[6]}$. Analisis ini dilakukan dengan teknik Monte Carlo yang mensimulasikan beberapa variabel ketidakpastian yang mungkin terjadi dalam proyek sebagai variabel masukan (input) dan dilihat pengaruhnya terhadap nilai NPV dan IRR sebagai keluaran (output). Penelitian 
dilakukan dengan membangun model deterministik terlebih dahulu kemudian dilanjutkan dengan analisis probabilistik. Dengan penelitian ini dapat diketahui tentang kelayakan finansial proyek PLTN SMR di Indonesia dengan mempertimbangkan kemungkinan terjadinya beberapa variabel ketidakpastian dalam proyek. Selain itu dengan analisis probabilistik ini juga dapat diketahui nilai probabilitas terjadinya NPV negatif jika proyek PLTN SMR tersebut dijalankan, sehingga hasil analisis ini diharapkan dapat menjadi masukan bagi calon investor dalam berinvestasi pada proyek PLTN SMR di wilayah LJB.

\section{METODOLOGI}

\subsection{Alur Penelitian}

Penelitian ini dilakukan melalui langkah-langkah yang dinyatakan dengan diagram alir pada Gambar 1 .

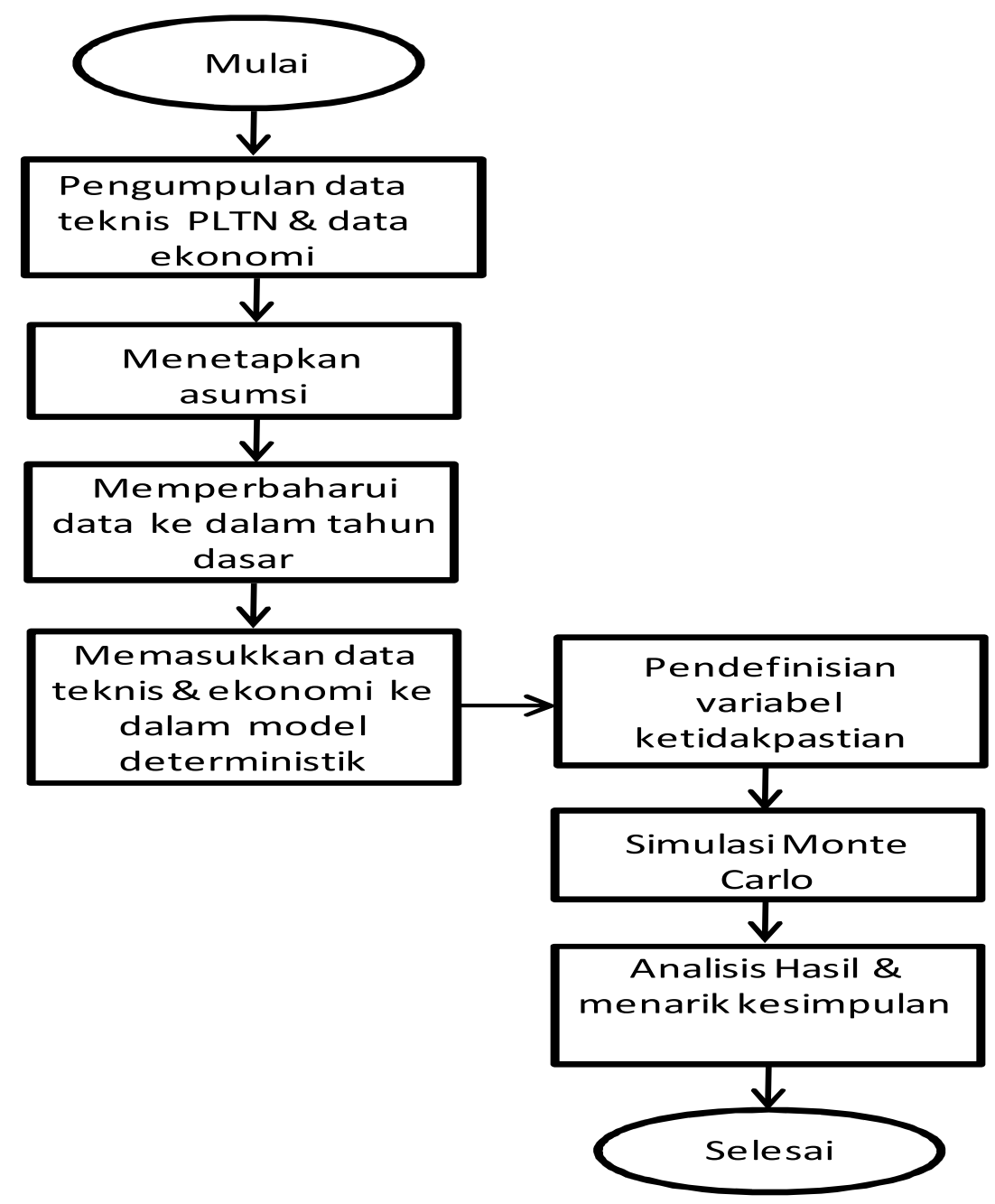

\section{Gambar 1. Diagram Alir Penelitian.}

\subsection{Teknik Simulasi Monte Carlo}

Pada dasarnya simulasi merupakan sebuah metode analitik yang bertujuan untuk membuat tiruan dari sebuah sistem yang mempunyai sifat acak ${ }^{[4]}$. Simulasi Monte Carlo didahului dengan pengembangan sebuah model deterministik yang memetakan suatu 
himpunan variabel masukan ke suatu himpunan variabel keluaran dengan beberapa persamaan. Skema tentang model deterministik dapat dilihat pada Gambar $2^{[7]}$.

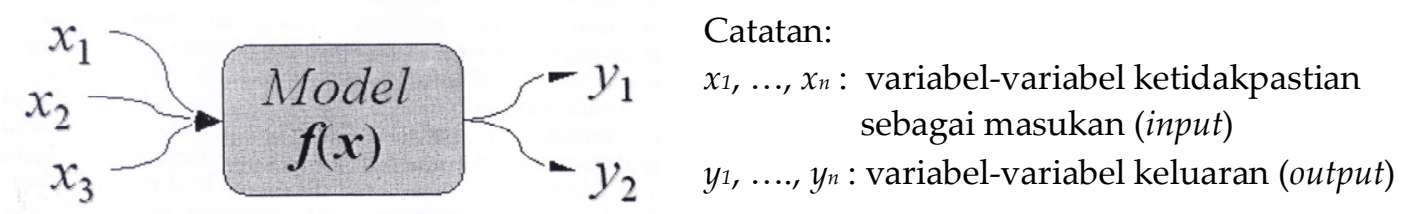

Gambar 2. Model Deterministik Parametrik ${ }^{[7]}$.

Dalam Simulasi Monte Carlo, model deterministik yang telah dikembangkan dievaluasi secara berulang menggunakan himpunan bilangan acak sebagai masukan. Metode ini sering digunakan bila model bersifat kompleks, nonlinear atau melibatkan banyak parameter tak tentu (uncertain) yang saling berhubungan. Perambatan ketidakpastian (uncertainty propagation) merupakan prinsip dasar di belakang simulasi Monte Carlo[ ${ }^{[5]}$. Skema dari prinsip perambatan ketidakpastian dapat dilihat pada Gambar 3.

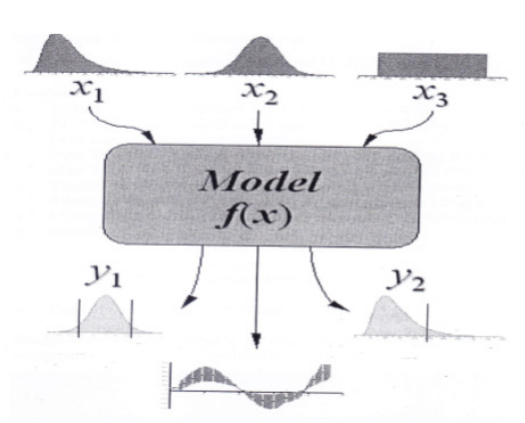

\section{Catatan:}

: Fungsi distribusi

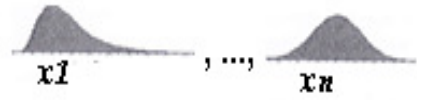
variabel-variabel ketidakpastian

Gambar 3. Skematis Perambatan Ketidakpastian ${ }^{[7]}$.

Langkah-langkah dalam simulasi Monte Carlo berdasar skema perambatan ketidakpastian tersebut adalah sebagai berikut ${ }^{[7]}$ :

Langkah 1: Buat suatu model parametrik, $\mathrm{y}=\mathrm{f}\left(\mathrm{x}_{1}, \mathrm{x}_{2}, \ldots ., \mathrm{x}_{\mathrm{q}}\right)$

Langkah 2: Bangkitkan suatu himpunan masukan acak, $\mathrm{x}_{\mathrm{i} 1}, \mathrm{x}_{\mathrm{i} 2}, \ldots, \mathrm{x}_{\mathrm{iq}}$

Langkah 3: Evaluasi model dan simpan hasilnya sebagai $\mathrm{yi}_{\mathrm{i}}$

Langkah 4: Ulangi langkah 2 dan 3 untuk $i=1$ sampai $n$

Langkah 5: Analisis hasil

\subsection{Indikator Kelayakan}

Indikator kelayakan proyek yang digunakan dalam analisis kelayakan finansial proyek PLTN SMR ini adalah NPVdan IRR.

a. Nilai Kini Bersih (Net Present Value - NPV)

Metode NPV menghitung selisih antara nilai kini dari investasi dengan nilai kini dari penerimaan kas bersih yang akan terjadi selama umur proyek. Formula untuk menghitung NPV diberikan pada persamaan $1^{[8]}$.

Keterangan:

$$
\begin{aligned}
\mathrm{NPV} & =-\mathrm{CF}_{0}+\frac{\mathrm{CF}_{1}}{(1+\mathrm{r})^{1}}+\frac{\mathrm{CF}_{2}}{(1+\mathrm{r})^{2}}+\cdots+\frac{\mathrm{CF}_{\mathrm{n}}}{(1+\mathrm{r})^{\mathrm{n}}} \\
& =-\mathrm{CF}_{0}+\sum_{\mathrm{t}=1}^{\mathrm{n}} \frac{\mathrm{CF}_{\mathrm{t}}}{(1+\mathrm{r})^{\mathrm{t}}}
\end{aligned}
$$

$\mathrm{CF}_{0}=$ Investasi awal 


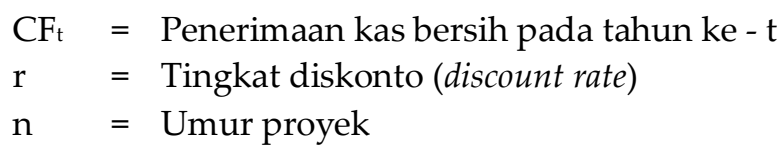

Kriteria penilaian kelayakan proyek berdasarkan NPV:

- Jika NPV >0, maka usulan proyek layak untuk dilaksanakan

- Jika NPV <0, maka usulan proyek tidak layak untuk dilaksanakan

- Jika NPV =0, maka usulan proyek tidak untung dan tidak rugi (impas)

b. Tingkat Pengembalian Internal (Internal Rate of Return- IRR)

IRR menginformasikan tingkat kemampuan cash flow proyek dalam mengembalikan investasi, yang dinyatakan dalam persentase ${ }^{[9]}$. Nilai IRR dibandingkan dengan MARR (Minimum Acceptable Rate of Return), yaitu tingkat pengembalian minimal yang masih dapat diterima oleh pelaku proyek ${ }^{[10]}$. Kriteria kelayakan berdasar nilai IRR adalah:

- Jika IRR > MARR, maka usulan proyek layak untuk dilaksanakan

- Jika IRR < MARR, maka usulan proyek tidak layak untuk dilaksanakan

- Jika IRR = MARR, maka pilih usulan proyek dengan risiko yang lebih kecil

Secara filosofi, IRR adalah nilai discount rate yang menyebabkan nilai NPV $=0$, artinya nilai kini investasi sama dengan nilai kini penerimaan kas bersih yang akan terjadi pada masa mendatang. Formula untuk menghitung IRR diberikan pada persamaan $2^{[8]}$.

$$
-\mathrm{CF}_{0}+\frac{\mathrm{CF}_{1}}{(1+\mathrm{IRR})^{1}}+\frac{\mathrm{CF}_{2}}{(1+\mathrm{IRR})^{2}}+\cdots+\frac{\mathrm{CF}_{\mathrm{n}}}{(1+\mathrm{IRR})^{\mathrm{n}}}=0
$$

\subsection{Parameter Tekno-ekonomi PLTN}

Sebelum dilakukan analisis kelayakan finansial, terlebih dulu didefinisikan beberapa parameter tekno-ekonomi dari PLTN yang dikaji sebagaimana dinyatakan pada Tabel 1.

Tabel 1. Parameter Tekno-Ekonomi PLTN SMR

\begin{tabular}{|c|c|c|c|c|}
\hline No & Parameter & Unit & Nilai & Referensi \\
\hline 1 & Kapasitas Pembangkit & MW & $2 \times 100$ & \\
\hline 2 & Faktor Kapasitas & $\%$ & 93 & JAPC $(2013)^{[11]}$ \\
\hline 3 & Produksi energi listrik tahunan & MWh & 1.629 .360 & \\
\hline 4 & Derajat bakar & $\begin{array}{l}\text { MWd per metric } \\
\text { ton U235 }\end{array}$ & 40.000 & $\begin{array}{l}\text { Rothwell } \\
(2014)^{[12]}\end{array}$ \\
\hline 5 & Pemakaian sendiri & $\%$ & 5,5 & \\
\hline 6 & Tahun Dasar & & 2013 & \\
\hline 7 & Waktu Konstruksi & Tahun & 5 & \\
\hline 8 & Umur Pembangkit & Tahun & 40 & \\
\hline 9 & Nilai tukar & Rp/US\$ & 10.504 & $\underline{\text { www.bi.go.id }}{ }^{13}$ \\
\hline 10 & Harga Jual Listrik & Cents US\$/kWh & 12 & \\
\hline 11 & Tingkat Diskonto (discount rate) & $\%$ & 10 & $\begin{array}{l}\text { Sekaligus } \\
\text { menjadi } \\
\text { MARR }\end{array}$ \\
\hline 12 & $\begin{array}{l}\text { Rasio Pinjaman terhadap } \\
\text { Equity }\end{array}$ & & $70 \%: 30 \%$ & \\
\hline 13 & $\begin{array}{l}\text { Porsi Pinjaman } \\
\text { Bank X (ECA 1) }\end{array}$ & $\%$ & 30 & \\
\hline
\end{tabular}




\begin{tabular}{|c|c|c|c|c|}
\hline No & Parameter & Unit & Nilai & Referensi \\
\hline & Bank Y (ECA 2) & $\%$ & 30 & \\
\hline & Bank Z (ECA 3) & $\%$ & 20 & \\
\hline & Bank A' (Bank Komersial) & $\%$ & 20 & \\
\hline 14 & CIRR untuk ECA & $\%$ & 3,27 & CIRR OECD ${ }^{[14]}$ \\
\hline 15 & $\begin{array}{l}\text { Tingkat Bunga Bank Komersial } \\
\text { (LIBOR }+5 \%)\end{array}$ & $\%$ & 5,7 & \\
\hline 16 & Tingkat Pajak & $\%$ & 25 & $\begin{array}{l}\text { UU No } 36 \text { th } \\
2008^{[15]}\end{array}$ \\
\hline 17 & Tingkat Inflasi US\$ & $\%$ & 1,5 & $\begin{array}{l}\text { http://data.bls. } \\
\text { gov/[16] }\end{array}$ \\
\hline 18 & Tingkat Inflasi Rp & $\%$ & 7,9 & $\underline{\text { www.bps.go.id }}{ }^{[17]}$ \\
\hline 19 & Eskalasi Harga Jual Listrik & $\%$ per tahun & 2 & \\
\hline 20 & Eskalasi Harga bahan bakar & $\%$ per tahun & 0,5 & \\
\hline 21 & Eskalasi Biaya O\&M & $\%$ per tahun & $\begin{array}{l}1,5 \% \text { (US\$) } \\
7,9 \% \text { (IDR) }\end{array}$ & \\
\hline
\end{tabular}

Terkait porsi pendanaan, proyek PLTN SMR ini diasumsikan didanai dengan $70 \%$ porsi pinjaman dan $30 \%$ porsi modal sendiri (equity). Komposisi porsi pinjaman ditunjukkan pada Tabel 2.

Tabel 2. Porsi Pinjaman Pada Pendanaan Proyek

\begin{tabular}{clrc}
\hline No & Jenis Bank & Porsi & Tingkat Bunga \\
\hline 1 & Bank X (ECA-1) & $30 \%$ & $3,27 \%$ \\
2 & Bank Y (ECA-2) & $30 \%$ & $3,27 \%$ \\
3 & Bank Z (ECA-3) & $20 \%$ & $3,27 \%$ \\
4 & Bank A' (Bank Komersial) & $20 \%$ & $5,70 \%$ \\
\hline
\end{tabular}

\subsection{Analisis Deterministik}

Analisis kelayakan finansial dilakukan dengan membangun model deterministik terlebih dahulu. Setelah data tekno ekonomi PLTN SMR dimasukkan ke dalam model maka diperoleh indikator kelayakan proyek yang dinyatakan pada Tabel 3.

Tabel 3. Hasil Analisis Kelayakan Proyek PLTN SMR dengan Pendekatan Deterministik

\begin{tabular}{ccr}
\hline No & Indikator & \multicolumn{1}{c}{ Nilai } \\
\hline 1 & NPV (US\$) & -214.322 .991 \\
2 & IRR proyek & $8,90 \%$ \\
3 & IRR Equity & $11,36 \%$ \\
\hline
\end{tabular}

Berdasar hasil pada Tabel 3 diketahui bahwa proyek PLTN SMR 2 × 100 MW tidak layak dijalankan pada harga jual listrik sebesar 12 cents US $\$ / k W h$ ditunjukkan oleh nilai NPV $<0$.

Selanjutnya dilakukan analisis sensitivitas untuk mengetahui pada harga jual listrik berapa proyek PLTN SMR dinilai layak. Hasil analisis sensitivitas dinyatakan pada Tabel 4. 
Tabel 4. Sensitivitas Harga Jual Listrik Terhadap Indikator Kelayakan Proyek PLTN SMR

\begin{tabular}{ccrcc}
\hline \multirow{2}{*}{ No } & Harga Jual & \multicolumn{3}{c}{ Indikator Kelayakan } \\
\cline { 3 - 5 } & (cents US\$/kWh) & \multicolumn{1}{c}{ NPV (US\$) } & IRR Proyek (\%) & IRR Equity (\%) \\
\hline 1 & 12 & -214.322 .991 & 8,90 & 11,36 \\
2 & 13 & -80.070 .490 & 9,60 & 12,85 \\
3 & 14 & 50.257 .132 & 10,24 & 14,28 \\
4 & 15 & 186.691 .007 & 10,89 & 15,64 \\
5 & 16 & 323.124 .882 & 11,51 & 16,97 \\
\hline
\end{tabular}

Berdasar Tabel 4 diketahui bahwa proyek PLTN SMR akan lebih atraktif jika dijalankan pada harga jual listrik minimal sebesar 15 cents US $\$ / k W h$, ditandai dengan nilai IRR proyek $>$ MARR dan NPV $>0$.

\subsection{Pendefinisian Variabel Ketidakpastian}

Rothwell (2011) mengidentifikasi 6 variabel yang berpotensi menyebabkan ketidakpastian dalam biaya pembangkitan listrik, antara lain: biaya investasi, waktu konstruksi, faktor kapasitas, biaya operasi \& perawatan, biaya $\mathrm{U}_{3} \mathrm{O}_{8}$ dan biaya pengkayaan $(\mathrm{SWU})^{[18]}$. Dalam penelitian ini diasumsikan bahwa variabel ketidakpastian yang berpengaruh terhadap kelayakan finansial mengacu pada Rothwell (2011) ditambah beberapa variabel yang berhubungan dengan parameter finansial, yaitu: LIBOR (London Inter Bank Offered Rate), nilai tukar, harga jual listrik dan tingkat inflasi[18].

Hasil pendefinisian distribusi dari seluruh variabel ketidakpastian tersebut dinyatakan pada Tabel 5 .

Tabel 5. Pendefinisian Distribusi dari Variabel Ketidakpastian

\begin{tabular}{|c|c|c|c|}
\hline No & Variabel Ketidakpastian & Jenis Distribusi & Keterangan \\
\hline 1 & Biaya investasi (US\$/kW) & $\begin{array}{l}\text { Triangular } \\
\text { minimum = 5.690; most } \\
\text { likely }=6.360 ; \text { maksimum } \\
=7.057\end{array}$ & $\begin{array}{l}\text { Pengepasan distribusi } \\
\text { dari data } \\
\text { historis }^{[18,19,20]}\end{array}$ \\
\hline 2 & $\begin{array}{l}\text { Spot Price Uranium alam }\left(\mathrm{U}_{3} \mathrm{O}_{8}\right) \\
(\mathrm{US} \$ / \mathrm{kg})\end{array}$ & $\begin{array}{l}\text { Pearson } 5 \\
\alpha=1,7211 \\
\beta=54,365\end{array}$ & $\begin{array}{l}\text { Pengepasan distribusi } \\
\text { dari data historis }{ }^{[21]}\end{array}$ \\
\hline 3 & $\begin{array}{l}\text { Spot Price Pengayaan Uranium } \\
\text { (SWU) }\end{array}$ & $\begin{array}{l}\text { Logistik } \\
\alpha=137,99 ; \beta=10,496\end{array}$ & $\begin{array}{l}\text { Pengepasan distribusi } \\
\text { dari data historis }{ }^{21]}\end{array}$ \\
\hline 4 & Faktor kapasitas (\%) & $\begin{array}{l}\text { Triangular } \\
\text { minimum = 88,65\%; } \\
\text { most likely =92,59\%; } \\
\text { maximum =99,19\% }\end{array}$ & $\begin{array}{l}\text { Pengepasan distribusi } \\
\text { dari data historis }{ }^{[21]}\end{array}$ \\
\hline 5 & Tingkat inflasi Rupiah (\%) & $\begin{array}{l}\text { Normal } \\
\text { Rata-rata }=7,937 \% \\
\text { Standar deviasi }=3,86 \%\end{array}$ & $\begin{array}{l}\text { Pengepasan distribusi } \\
\text { dari data historis }{ }^{[17]}\end{array}$ \\
\hline 6 & Nilai tukar (Rupiah/US\$) & $\begin{array}{l}\text { Lognorm }(792,51) \\
\mu=1.733,3 \\
\sigma=792,51\end{array}$ & $\begin{array}{l}\text { Pengepasan distribusi } \\
\text { dari data historis }{ }^{[13]}\end{array}$ \\
\hline
\end{tabular}




\begin{tabular}{|c|c|c|c|}
\hline No & Variabel Ketidakpastian & Jenis Distribusi & Keterangan \\
\hline \multirow[t]{4}{*}{7} & Harga Jual listrik (Cents & Triangular & {$[11,22]$} \\
\hline & US\$/kWh) & Minimum $=12$ & \\
\hline & & Most Likely $=15$ & \\
\hline & & Maksimum $=18$ & \\
\hline \multirow[t]{4}{*}{8} & LIBOR (\%) & Triangular & Pengepasan distribusi \\
\hline & & Minimum $=0,578 \%$ & dari data historis ${ }^{[23]}$ \\
\hline & & Most Likely $=2,54 \%$ & \\
\hline & & Maksimum $=6,468 \%$ & \\
\hline
\end{tabular}

\section{HASIL DAN PEMBAHASAN}

Analisis kelayakan finansial proyek PLTN SMR 2x100 MW dengan mempertimbangkan variabel ketidakpastian ini dilakukan dengan teknik simulasi Monte Carlo. Simulasi dilakukan menggunakan paket program @Risk, dengan 1000 kali iterasi. Tabel 6 menunjukkan statistik hasil simulasi variabel ketidakpastian terhadap indikator kelayakan finansial.

Tabel 6. Hasil Simulasi Variabel Ketidakpastian Terhadap Indikator Kelayakan Finansial

\begin{tabular}{lccc}
\hline \multirow{2}{*}{ Statistik } & \multicolumn{3}{c}{ Indikator Kelayakan Finansial } \\
\cline { 2 - 4 } & NPV (US\$) & IRR Proyek (\%) & IRR Equity (\%) \\
\hline Minimum & -862.805 .725 & 5,45 & 5,49 \\
Maksimum & 641.594 .310 & 13,02 & 19,96 \\
Rata-rata & 135.324 .004 & 10,65 & 14,29 \\
Standar deviasi & 186.420 .081 & 0,89 & 1,84 \\
\hline
\end{tabular}

Berdasar Tabel 6 diketahui bahwa nilai rata-rata NPV yang diperoleh dari simulasi variabelvariabel ketidakpastian bernilai positif (US\$ 135.324.004) dan rata-rata kedua IRR (baik IRR proyek maupun IRR equity masing-masing sebesar 10,65\% dan 14,29\%) lebih besar dari MARR. Karena rata-rata NPV $>0$ dan rata-rata kedua IRR $>$ MARR, maka disimpulkan bahwa dengan pendekatan probabilistik proyek PLTN SMR dinilai layak dijalankan pada most probable value harga jual listrik sebesar 15 cent US $\$ / \mathrm{kWh}$.

Standar deviasi merupakan ukuran dispersi dari suatu variabel, oleh karena itu secara statistik nilai variabel sering dinyatakan dengan rata-rata \pm standar deviasi. Jika dinyatakan secara statistik, nilai indikator kelayakan finansial pada Tabel 6 akan menjadi: NPV = US\$ 135,324,004 \pm US\$ 186.420.080, IRR proyek $=10,65 \% \pm 0,89 \%$ dan IRR Equity $=14,29 \% \pm$ $1,84 \%$. Tanda " \pm " mengindikasikan bahwa nilai variabel tersebut berada dalam interval ratarata \pm standar deviasi. Nilai NPV akan berada pada interval US\$ 51.096 .076 US\$ 321.744.084, IRR proyek pada interval 9,76\% - 11,54\% dan IRR Equity pada interval $12,45 \%-16,13 \%$. Dengan menggunakan indikator kelayakan finansial dalam bentuk ratarata \pm standar deviasi tersebut, maka dapat diketahui probabilitas ditolaknya proyek PLTN SMR, yaitu dengan melihat probabilitas NPV negatif atau probabilitas IRR $<$ MARR.

Gambar 4 dan 5 menyatakan fungsi distribusi kumulatif NPV dan IRR proyek sebagai hasil simulasi variabel-variabel ketidakpastian. Berdasar fungsi distribusi kumulatif NPV atau IRR proyek tersebut dapat diketahui probabilitas ditolaknya proyek PLTN SMR. 


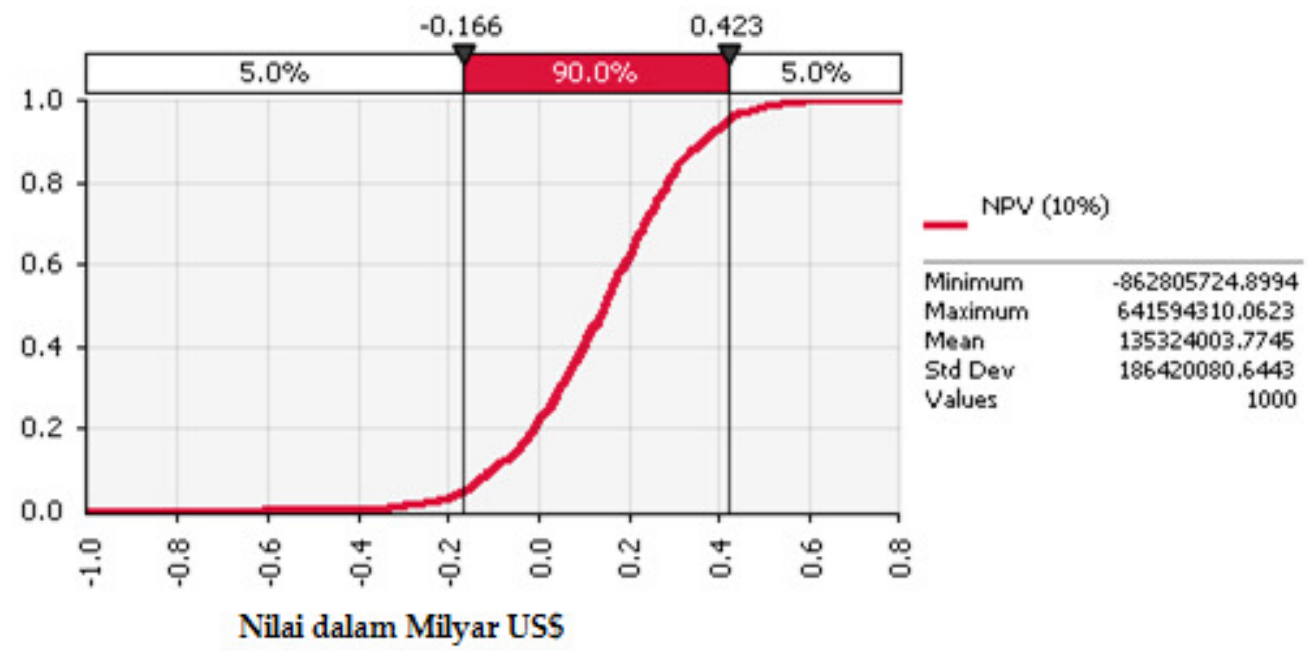

\section{Gambar 4. Fungsi Distribusi Kumulatif NPV sebagai Hasil Simulasi Variabel Ketidakpastian.}

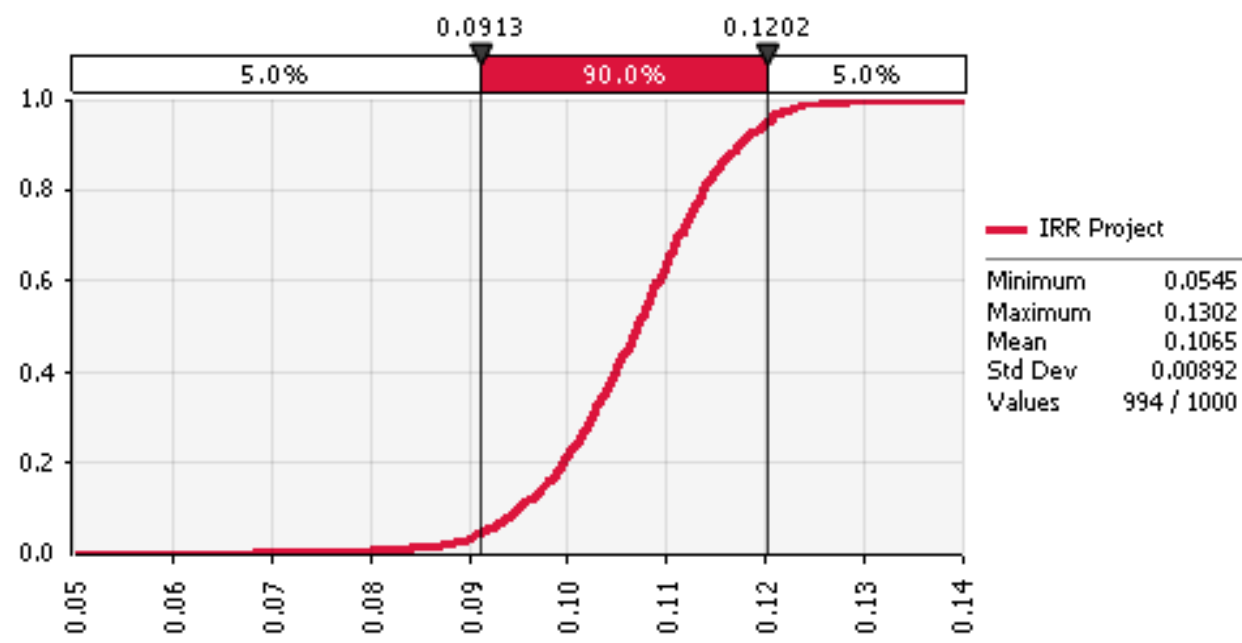

Gambar 5. Fungsi Distribusi Kumulatif IRR Proyek sebagai Hasil Simulasi Variabel Ketidakpastian.

Berdasar Gambar 4 dan 5 diketahui bahwa probabilitas NPV negatif (NPV $<0$ ) dan probabilitas IRR proyek < MARR sebesar 20\%. Artinya terdapat probabilitas sebesar $20 \%$ proyek PLTN SMR 2 × 100 MW tersebut tidak layak dijalankan.

Gambar 6 dan 7 menunjukkan diagram Tornado dari NPV dan IRR proyek PLTN SMR. Diagram ini memuat koefisien regresi masing-masing variabel ketidakpastian dan pada dasarnya menyatakan seberapa kuat hubungan antara variabel ketidakpastian terhadap kelayakan finansial. Dengan diagram ini dapat diidentifikasi variabel mana saja yang sangat berpengaruh terhadap indikator kelayakan finansial proyek. 


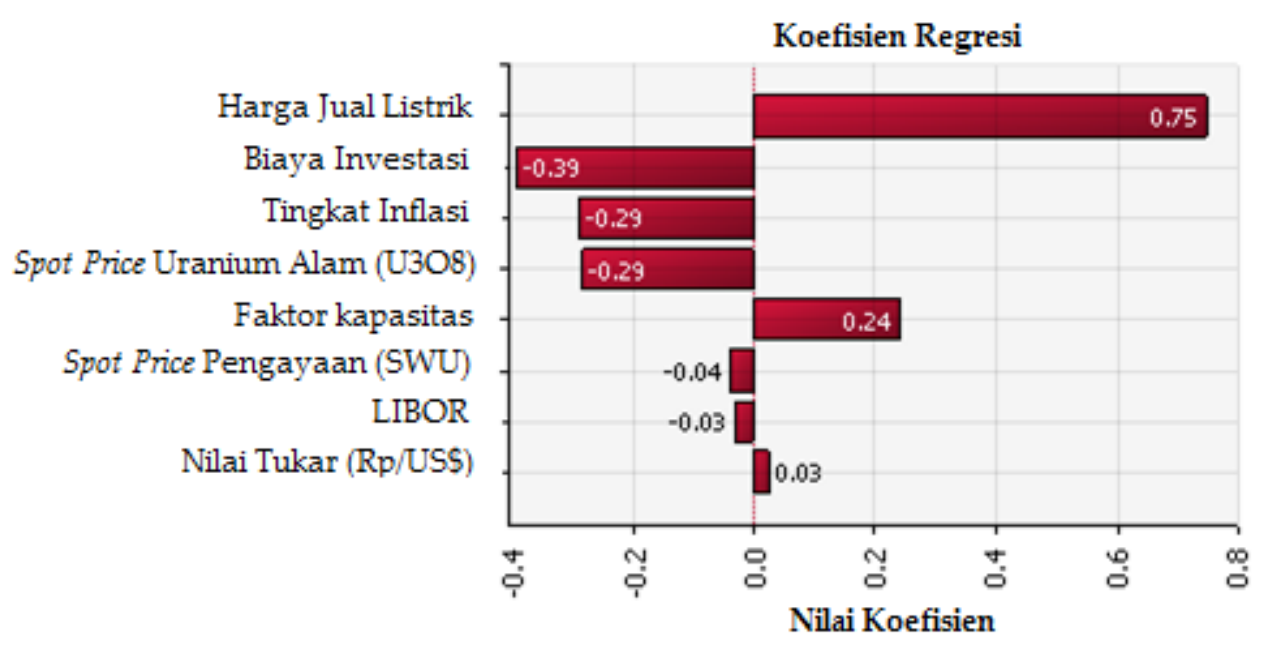

Gambar 6. Diagram Tornado NPV sebagai Hasil Simulasi Variabel Ketidakpastian.

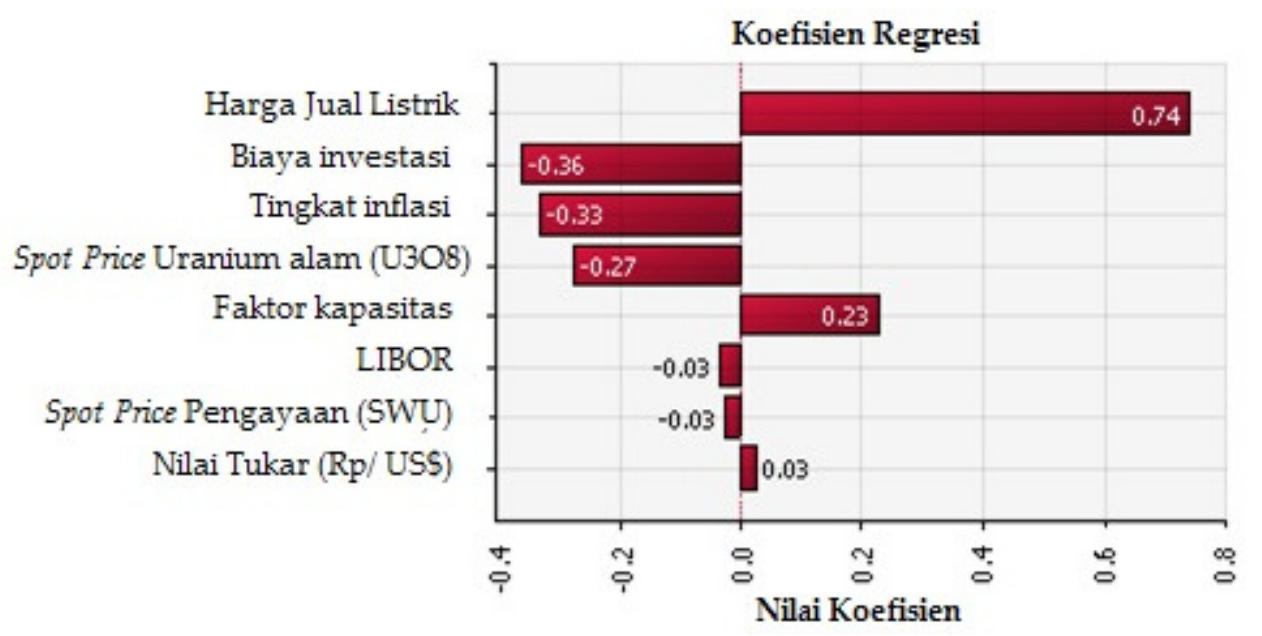

Gambar 7. Diagram Tornado IRR Proyek sebagai Hasil Simulasi Variabel Ketidakpastian.

Pada Gambar 6 dan 7 diketahui bahwa tiga variabel utama yang mempengaruhi NPV dan IRR proyek adalah: harga jual listrik (cents US $\$ / k W h$ ), biaya investasi (US $\$ / k W e$ ) dan tingkat inflasi. Oleh karena itu, ketiga variabel ini sangat krusial untuk dimonitor guna meningkatkan probabilitas diterimanya proyek PLTN SMR.

\section{KESIMPULAN}

PLTN SMR merupakan salah satu alternatif mengatasi ketergantungan wilayah LJB terhadap pembangkit berbahan bakar minyak. Pendekatan probabilistik dalam analisis kelayakan finansial terbukti mampu mengakomodasi kemungkinan terjadinya variabelvariabel ketidakpastian dalam proyek PLTN SMR. Pada pendekatan deterministik, proyek PLTN SMR dinilai tidak layak pada harga jual listrik sebesar 12 cents US $\$ / k W h$ dan akan lebih atraktif pada harga jual listrik minimal sebesar 15 cents US $\$ / k W h$. Pada pendekatan probabilistik, proyek PLTN SMR dinilai layak dijalankan pada "most probable value" harga jual listrik sebesar 15 cents/kWh, ditunjukkan dengan rata-rata NPV yang positif (US\$ 135.324.004) dan rata-rata kedua nilai IRR yang lebih besar dari MARR (IRR proyek = 10,65\% dan IRR Equity $=14,29 \%$ ). Dengan pendekatan probabilistik dapat diketahui probabilitas ditolaknya proyek PLTN SMR yaitu sebesar 20\%, artinya terdapat probabilitas sebesar $80 \%$ proyek PLTN SMR akan layak dijalankan. Berdasar diagram Tornado, 
diketahui bahwa terdapat tiga variabel utama yang paling berpengaruh terhadap kelayakan finansial proyek PLTN SMR, yaitu: harga jual listrik, biaya investasi dan tingkat inflasi.

\section{DAFTAR PUSTAKA}

[1]. RAMADHANI, E., "Penelitian Stabilitas Sistem Interkoneksi Serawak - Kalimantan Barat", Proceeding Seminar Tugas Akhir Jurusan Teknik Elektro FTI-ITS, 2012.

[2]. PT. PLN (Persero), "Statistik PLN 2014", Jakarta, 2014.

[3]. IEA/ NEA, "Current Status. Technical Feasibility and Economics of Small Nuclear Reactors", OECD, Paris, June 2011.

[4]. LOCATELLI, G \& MANCINI, M.,"Small-Medium Sized Nuclear, Coal and Gas Power Plant: A Probabilistic Analysis of Their Performances and Influence of CO2 Cost", Energy Policy, p. 38, 6360-6374, 2010.

[5]. RODE, at al, "Montecarlo Methods for Appraisal and Valuation: A Case Study of a Nuclear Power Plant", CEIC Working Paper 01-01, Carnegie Mellon Electricity Industry Center, Carnegie Mellon University, Pittsburgh, 2001.

[6]. SOEHARTO, I., "Penelitian Kelayakan Proyek”, Penerbit Erlangga, Jakarta, 2002.

[7]. SRIDADI, B.,"Pemodelan dan Simulasi Sistem: Teori, Aplikasi dan Contoh Program dalam Bahasa C", Penerbit Informatika, Jakarta, 2009.

[8]. BLANK \& TARQUIN, “Engineering Economy", 6th, Mc Graw Hill, Singapore, 2008.

[9]. PERMATASARI, K.,"Analisis Kelayakan Proyek Pembangunan Pembangkit Listrik Tenaga Panas Bumi oleh Pengembang Panas Bumi di Indonesia", Skripsi, Jakarta: Program Penelitian Teknik Industri Universitas Indonesia, 2010.

[10]. MARTLAND, CARL D., "Project Evaluation Choosing a Discount Rate", http://ocw.mit.edu/courses/civil-and-environmental-engineering/1-011-project evaluation-spring-2011/lecture-notes/MIT1_011S11_lec06.pdf. diakses 26 Maret 2012.

[11]. PT PLN (Persero), PT LAPI ITB \& JAPC,"Feasibility Study for Bangka Nuclear Power Plant Project - Non Site aspect", 2013.

[12]. ROTHWELL, G. \& GANDA, F., "Electricity Generating Portfolios with Small Modular Reactors", Argonne National Laboratory, May 2014.

[13]. BANK INDONESIA, "Foreign Exchange Rate in Year 2013", http://www.bi.go.id/. Diakses 01 Juni 2014.

[14]. OECD, "Commercial Interest Reference Rate (CIRRs)", www.oecd.org/tad/xcred/cirrs.pdf. Diakses 01 Juni 2014.

[15]. _UU No 36 tahun 2008 Tentang Perubahan Keempat Atas UU No. 7 Tahun 1983 Tentang Pajak Penghasilan", Kementerian Hukum \& HAM, 2008.

[16]. _CPI Inflation Calculator", http://data.bls.gov/cgi-bin/cpicalc.pl. Diakses 03 Juli 2015.

[17]. “Indeks Harga Konsumen dan Inflasi Bulanan Indonesia, 2005 - 2015", http://www.bps.go.id/linkTabelStatis/view/id/907. Diakses 03 Juli 2015.

[18]. ABDULLA, A. \& AZEVEDO, I. L., “Developing a Range of Levelized Cost Estimates for Integral Light Water Small Modular Reactor", www.andrew.cmu.edu. Diakses Mei 2014.

[19]. US DEPARTMENT OF ENERGY, "SMR Financing and Economics, The Nuclear Option: Is Small Scale Nuclear Energy an Option for Alaska?", December 2010.

[20]. ONO, K., “Generation IV International Forum Economics Assessment Methodology andApplication", GIF-INPRO Interface Meeting, Vienna, March 1, 2013.

[21]. ROTHWELL, "The economics of future nuclear power: an update of the economic future of nuclear power (2004), a study conducted at the University of Chicago", 
Analisis Kelayakan Finansial Proyek PLTN SMR di Indonesia Dengan Mempertimbangkan Variabel

Ketidakpastian

(Nuryanti, dkk)

Stanford University, 2011.

[22]. KESDM, "Peraturan Menteri ESDM No. 3 Tahun 2015", Jakarta, 2015.

[23]. _What is LIBOR Rate", http://www.moneycafe.com/personal-finance/libor/. Diakses Mei 2014. 